\title{
Western blot assay of anti-Echinococcus granulosus antibody positive serum samples by indirect haemagglutination method
}

\author{
İndirekt hemagluitinasyon yöntemiyle anti-Echinococcus granulosus \\ antikorları pozitif saptanan serum örneklerinin \\ western blot testi ile değerlendirilmesi
}

\section{Ayşe Semra GÜRESER ${ }^{1}$, Gamze Gizem DUMAN² ${ }^{2}$ Fakhriddin SARZHANOV ${ }^{3}$, Djursun KARASARTOVA ${ }^{1}$, Funda DOGRUMAN-AL', Ayșegül TAYLAN-OZKAN ${ }^{1}$}

\section{ABSTRACT}

Objective: Cystic echinococcosis (CE) is a zoonotic disease mainly caused by the larvae of Echinococcus granulosus which is common in rural areas in Turkey. A multidisciplinary approach consisting of clinicians, radiologists and microbiologists is required for the proper diagnosis of the disease. Enzyme-linked immunosorbent assay (ELISA) and indirect hemagglutination (IHA) tests are preferred in the primer diagnosis of cystic echinococcosis (CE), while western blot (WB) is used to confirm the disease. However the use of serologic tests alone in diagnosis and follow-up of the disease is not recommended due to variable sensitivity and specificity rates and multiple serologic tests are required for appropriate diagnosis. In this study, it was aimed to compare the test results of patients sera sent to Gazi University Medical Faculty Microbiology Laboratory, between December 2015 and December 2016, with the preliminary diagnosis of $\mathrm{CE}$, by WB test after those titrated with IHA. It is also aimed to determine the consistency between the two tests.

Methods: CE suspicious specimens were first tested

\section{ÖZET}

Amaç: Echinococcus granulosus larvasının insanlarda sebep olduğu kistik ekinokokkoz (KE), ülkemizde hayvancılığın yoğun olarak yapıldığı bölgelerde yaygın görülen ve tanı için klinisyen, radyolog ve mikrobiyologların multidisipliner yaklașımını gerektiren bir zoonozdur. Enzim-linked immünassay (ELISA) ve indirekt hemaglütinasyon (IHA), hastaların tanısında ilk sırada tercih edilirken Western Blot (WB) testi daha çok doğrulama amacıyla kullanılmaktadır. Fakat serolojik testlerin hastalığın tanı ve takibinde tek bașına kullanımı, değișken duyarlılık ve özgüllük oranları nedeniyle önerilmemekte, uygun tanı için birden fazla serolojik testin kullanımı gerekmektedir. Bu çalıșmada, Aralık 2015-2016 tarihleri arasında Gazi Üniversitesi Tıp Fakültesi Mikrobiyoloji Laboratuvarı'na KE șüphesiyle gönderilen hasta serumlarında IHA yöntemiyle titrasyon veren örneklerin doğrulama testi olarak kabul edilen WB yöntemi ile değerlendirilmesi ve iki test arasındaki tutarlılığın saptanması amaçlanmıștır.

Yöntem: KE șüpheli örnekler, $E$. granulosus antijenleri ile hazırlanmıș IHA (Fumouze Laboratoires,

'Hitit University, Faculty of Medicine, Department of Medical Microbiology, Çorum

${ }^{2}$ Sütçü İmam University, Faculty of Medicine, Department of Ophthalmic Surgery, Kahramanmaraş

${ }^{3} \mathrm{Gazi}$ University, Faculty of Medicine, Department of Medical Microbiology, Ankara

DOI ID : 10.5505/TurkHijyen.2019.03779

Güreser AS, Duman GG, Sarzhanov F, Karasartova D, Dogruman-Al F, Taylan-Ozkan A. Western blot assay of anti-Echinococcus granulosus antibody positive serum samples by indirect haemagglutination method. Turk Hij Den Biyol Derg, 2019; 76(2): 195-202 
by the IHA method (Fumouze Laboratoires, France) prepared with $E$. granulosus antigens. Afterwards 54 samples were tested again with the WB method (Anti-Echinococcus EUROLINE-WBIgG, Germany). The presence and intensity of antigen bands on the WB strips was assessed using commercial EUROLINE Scansoftware.

Results: Of the 54 cases, we found that $44(81.48 \%)$ were positive with IHA test while 46 (85.19\%) of them were positive with WB method. Six patients $(11.12 \%)$ were positive with WB while they were negative by the IHA (< 1/320 titer). Two of them were IHA-negative in the titer $1 / 80$, four in the titer $1 / 160$. Cohen's Kappa analysis showed fair (slight) consistency $(\mathrm{K}=0.26)$ between the two tests.

Conclusion: As a result, using only IHA test can miss out $\mathrm{CE}$ patients therefore, the combined use of immunoassay tests increases the sensitivity in diagnosis. In the case of screening with IHA and confirmation with WB, for the more accurate results, analysis of all sera titrating with IHA from $1 / 80$ is recommended with WB, even if it is negative according to kit procedures.

Key Words: Cystic echinococcosis, serology, diagnosis, indirect haemagglutination test, western blot
Fransa) yöntemi ile analiz edilmiş, titre veren 54 örnek doğrulama testi kabul edilen WB (Anti-Echinococcus EUROLINE-WBIgG, Almanya) yöntemi ile tekrar çalıșılmıștır. WB stripleri üzerindeki antijen bantlarının varlığı ve yoğunluğu ticari EURO-LineScan yazılımı kullanılarak değerlendirilmiștir.

Bulgular: 54 hastanın $44(\% 81,48)$ 'ü IHA ile pozitif saptanırken, WB yöntemi ile $46(\% 85,19)$ 'sı pozitif olarak saptanmıștır. Altı $(\% 11,12)$ hasta IHA ile negatif $(<1 / 320$ titre) olarak saptanırken WB testi ile pozitif olarak saptanmıștır. Bunlardan iki tanesi 1/80, dört tanesi de 1/160 titrede IHA negatif olarak saptanmıștır. Cohen's Kappa analizi ile iki test arasında düșük (fair, slight) tutarlılık olduğu saptanmıștır.

Sonuç: Sonuç olarak KE tanısında sadece IHA testi ile pozitif olan hastalar atlanabilmekte; bu nedenle immüntanısal testlerin birlikte kullanımı tanıda duyarlılığı arttırmaktadır. IHA ile tarama, WB ile doğrulama yapılması durumunda kit kullanım kılavuzuna göre negatif olarak değerlendirilse dahi daha doğru sonuç verme açısından $1 / 80$ 'den itibaren titrasyon veren tüm serumların WB ile analizi önerilir.

Anahtar Kelimeler: Kistik ekinokokoz, seroloji, tanı, indirekt hemaglütinasyon testi, western blot

\section{INTRODUCTION}

Cystic echinococcosis, (CE) caused by larval form of the Echinococcus granulosus is endemic in many regions of the world, such as western and central Asia, south and south-eastern Europe and Middle East as well as in Turkey (1-11). The disease is a zoonosis and occurs after eggs of the parasite are being ingested by humans. The oncospheres hatch and penetrate the intestinal mucosa, enter the blood or lymphatic vessels and spread in the internal organs to form the fluid-filled cyst structure (12). Patients with CE are usually asymptomatic and it is possible to discover cysts by imaging methods incidentally (13). In general, only large cysts can cause clinical symptoms in humans, symptoms of the disease are nonspecific and vary according to the location of cysts. Clinical findings may be confused with the findings of the benign cysts, cavitary tuberculosis, mycoses, benign and malign tumors (7). 
Radiological imaging methods, including ultrasonography, computed tomography (CT) and magnetic resonance imaging (MRI), are important for the diagnosis of CE but serological tests have only a complementary role in the diagnosis because of the low sensitivity and low specificity due to crossreactions with a plenty of diseases (14-18). Sensitivity of serological tests was reported as $88-96 \%$ in liver cysts, $50-56 \%$ in lung cysts and $25-26 \%$ in other organ cysts (15). However, serology may provide valuable information when imaging studies are insufficient.

The most commonly used serological tests are indirect haemagglutination (IHA), enzyme-linked immunosorbent assay (ELISA), indirect fluorescent antibody (IFA) and immunoblotting tests that detect specific IgG antibodies (7, 16, 19-23). The western blot (WB) test, one of the immunoblotting methods, is used for confirmation, while ELISA and IHA are the first-line tests for CE diagnosis (14, 19, 20, 22). Although the IHA test was considered to have variable (60-100\%) sensitivity and poor specificity, it is one of the most frequently used test to screen CE (24, 25). Positive test results should be confirmed by immunoblotting although this technique is not widely available (26).

As a result, there is no standard serological test with high sensitivity and specificity that can be used in CE diagnosis today. This is due to the fact that the sensitivity and specificity of serological tests are influenced by a number of factors, such as the quality of the used antigen, location, number and size of the cysts and the individual differences in immunological response of the patients (27). For this reason, many laboratories use, at least two different serological tests, together to increase sensitivity in the diagnosis of CE (12).

In this study, we used IHA test as a screening test and WB assay as a confirming test in patients, who were prediagnosed CE. The aim was to determine whether there is consistency between the two tests.

\section{MATERIAL and METHOD}

The present study included serum samples from 54 patients of both genders and different ages, with CE that presented between December 2015 and 2016 at the Gazi University Faculty of Medicine in Ankara, Turkey. The diagnosis of CE is confirmed by clinical findings, characteristic abnormalities in diagnostic imaging and demonstration of specific antibodies against Echinococcus spp. The presence of specific antibodies against Echinococcus species was demonstrated by two of the following tests: indirect haemagglutination (IHA, Fumouze, France) and WB (Anti-Echinococcus EUROLINE-WB IgG, Germany).

Samples were first studied with IHA (Fumouze Laboratories, France) prepared with E. granulosus antigens to detect antibodies. Serum was diluted to $1 / 80,1 / 160$, and $1 / 320$ for IHA and the test was repeated at the upper titers $(1 / 640,1 / 1280$, $1 / 2560$ ) when positive results were detected. In the test using antigenic red cell suspension, after 2 hours of incubation, a button-like precipitate was considered negative, while a serrated and lenticular appearance was considered positive. According to the manufacturer's recommendations $\geq 1 / 320$ antibody titration were evaluated as positive for CE.

All IHA positive sera with low, mid-range, and high titers were secondly retested with WB method (AntiEchinococcus EUROLINE-WBIgG, Germany), which accepted as confirmation test. The commercially developed WB assay contains electrophoretically separated $E$. multilocularis metacestode vesicle fluid antigens; p25/26 (25-26kDa), p16/18(16$18 \mathrm{kDa})$, p21 and p7 antigens and three membrane chips with recombinant $E$. granulosus antigen AgB8 plus E. multilocularis antigens Em18 and Em95. The presence and intensity of antigen bands on the WB strips were assessed using the commercial EUROLine Scan software. The manufacturer reported that the sensitivity of the WB test was $93 \%$ and the specificity was $100 \%$. 
Consistency analysis of the test results was statistically evaluated by Cohen's Kappa analysis (28).

\section{RESULTS}

Of the 54 serum samples, 44 (81.48\%) were positive and ten (18.52\%) were negative with IHA test. Forty-six $(85.19 \%)$ of the samples were positive, seven $(12.96 \%)$ were borderline and one $(1.85 \%)$ was negative for $E$. granulosus antibody with WB method.

Six serum samples (11.12\%) were detected as positive with WB while they were detected as negative by the IHA test ( $<1 / 320$ antibody titer). Two of them were IHA-negative in the titer $1 / 80$, four in the titer $1 / 160$.

Three samples were detected as borderline with WB while they were negative with IHA. One $(1.85 \%)$ of them was IHA-negative in the titer 1/80, two (3.71\%) of them were IHA-negative in the titer $1 / 160$.
One serum sample IHA-negative in the titer $1 / 160$ was found as negative with WB method.

Four samples (7.4\%) were found that were borderline with WB but positive with IHA test $(\geq$ 1/320). Two (3.771\%) of them were IHA-positive in the titer $1 / 320$, one $(1.85 \%)$ in the titer $1 / 1280$, and the other one $(1.85 \%)$ in the titer $1 / 2560$. When the blot test results of these patients were reviewed again, it was seen that all of the IgG and EgAgB bands were positive.

Coherence analysis was performed with Cohen's Kappa analysis, with a Kappa value of 0.22 and a weighted Kappa value of 0.26 . In this analysis, it is accepted that values above 0.2 indicate consistency, and in our study it was determined that there was fair (slightly) consistency in the Cohen's Kappa analysis between IHA and WB tests.

A comparison of the results of the IHA and WB methods of serum samples is shown in Table1.

Table 1. WB and IHA test results of serum samples

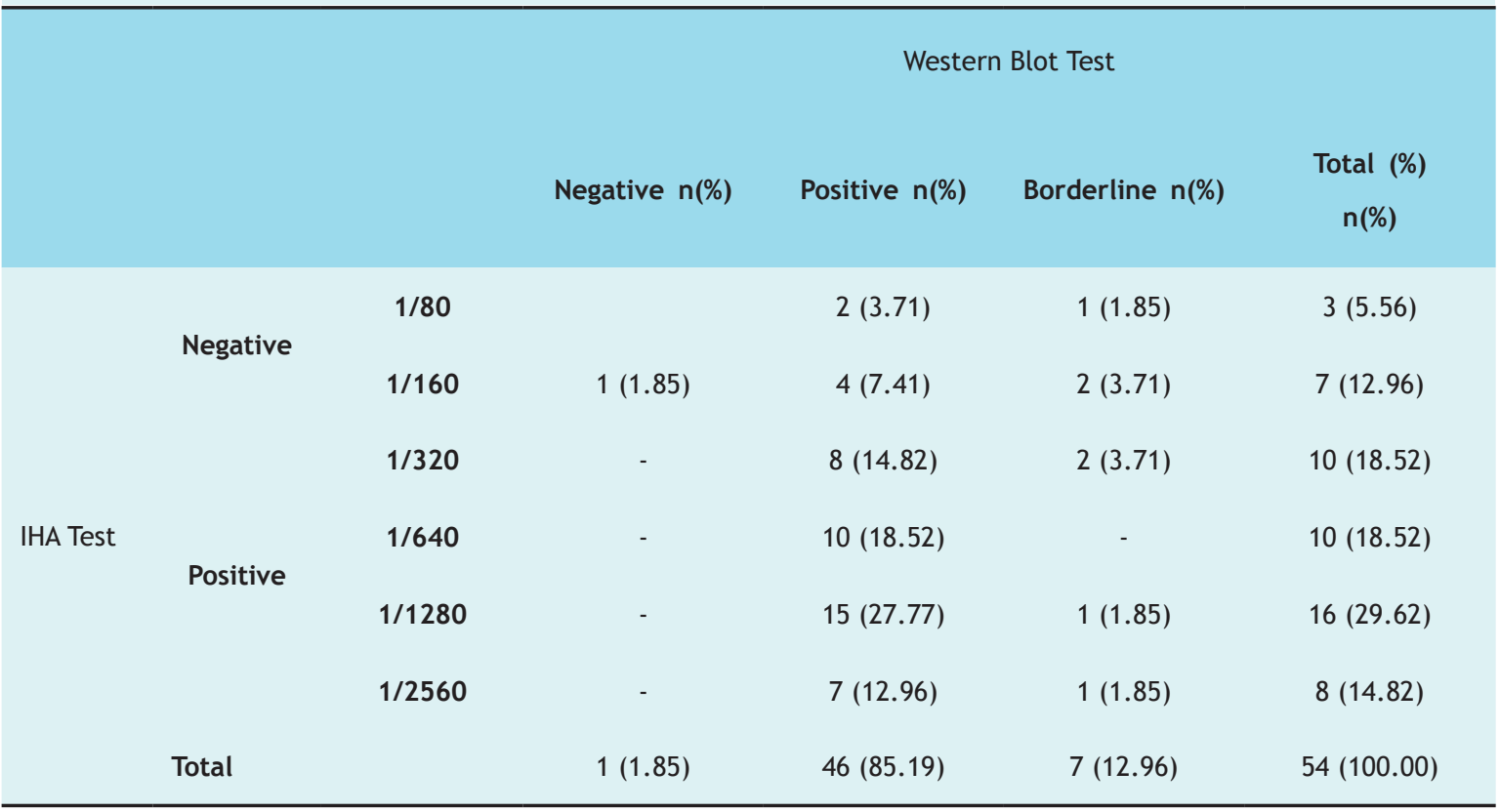




\section{DISCUSSION}

The use of serological tests in the diagnosis of CE and follow-up of patients has not been achieved at the desired level and it remains to be discussed which test should be selected for diagnosis and follow-up. There are a number of diagnostic tests based on ELISA, IHA, and immune-chromatography available for $C E$ diagnosis, including either unprocessed natural antigens of the hydatic fluid or semi-purified fractions of the this antigenic mixture (14). In particular, test methods involving $E$. granulosus natural antigens are not sensitive and their specificity is not at the desired levels due to cross-reactions with cysticercosis, fasciolosis, filariasis and other helminth infections (12). It has been reported in the literature that serology could be detected as positive in $80-94 \%$ of the cases of CE while only $65 \%$ of the cases in the alveolar echinococcosis (7). The rate of false-positivity in current tests are high, because of the cross reactivity with other parasites, especially in infected patients with cestodes, and even in healthy individuals (29). In addition, serological tests are ineffective to determine inactive (treated or calcific cyst) or active (active and progressive cyst) disease (30). Therefore, a positive serology result should be confirmed by more specific secondary tests in cases where cyst cannot be clearly detected by radiological imaging methods. Secondary assays are immunoblot tests generated with $E$. granulosus antigens, the detection of specific IgG subtypes and arc five precipitation tests, which are generally less sensitive but more specific than the primary test systems $(12,22)$.

Today, the gold standard in the serological diagnosis of the disease is the detection of lgG antibodies by either ELISA or immunoblotting, using natural or recombinant antigen $B$ subunits originating from cyst fluid (31). However, the difficulty of the standardization of the preparation techniques of the antigens and the limitations of the use of the appropriate source of antigen material significantly influence the performance of these assays (32). It was reported that the combined use of immune-based tests in CE diagnosis will increase the diagnostic sensitivity $(7,19,20)$.

In our study, we used IHA test as a screening test and WB assay as a confirming test in patients, who were prediagnosed $\mathrm{CE}$. The aim was to determine whether there is consistency between the two tests. The IHA test was preferred because it is an easy, reliable, and short-term result, especially in serological diagnosis. IHA (Fumouze Laboratories, France) was tested by various investigators and reported with a sensitivity ranging from $34.9-88 \%$ and specificity ranging from $44-70 \%(20,33,34)$.

Of the 54 cases, we found that $44(81.48 \%)$ were positive with IHA test while $46(85.19 \%)$ of them were positive with WB method. Although the WB test used for CE diagnosis had a higher sensitivity than the ELISA and IHA tests $(20,22,35)$, there were also studies reporting different results in the literature $(36,37)$. In a study in which 1323 patients with suspected CE disease were screened, only $48(37.7 \%)$ were found to be positive by the WB method from 127 sera, which were found to be positive by the IHA method, while the others were found to be negative (36). We found that $40(90 \%)$ of $44 \mathrm{IHA}$ positive patients were positive and 4 patients were negative with WB, for CE. Of the four patients $(7.4 \%)$, two $(3.771 \%)$ of them were IHA-positive in the titer $1 / 320$, one $(1.85 \%)$ in the titer $1 / 1280$, and the other one $(1.85 \%)$ in the titer $1 / 2560$. When the blot test results of these patients were reviewed again, it was seen that all of the lgG and EgAgB bands were positive. But according the kit procedure they considered as "borderline" due to the presence of only one of the p7, p21 or p25/26 patterns. It is thought that, the incompatibility of the WB and IHA tests in these patients may be related to the immunity of the patients, the location of the cyst, the size of the cyst, the number of cysts and even the genotype of the parasite $(7,12,14,19$, $24,25,27,38)$. Therefore, the detection of EgAB and specific lgG bands in the blot results may be 
indicative of disease diagnosis, even if the WB test is detected at the borderline. It was indicated that AgB is a polymeric lipoprotein with a molecular weight of $120 \mathrm{kDa}$ and had an important role in relation to parasite biology and parasite host (39). We found six patients (11.12\%) were positive with WB while they were negative by the IHA test $(<1 / 320$ antibody titer). Two of them were IHA-negative in the titer $1 / 80$, four in the titer $1 / 160$. False negativity in IHA tests may be related to patient-related factors such as the number of cysts, localization, size, age, immunity of the patient, and treatment (40). Akçam et. al. (41), reported that $23.1 \%$ of 134 patients, with extra-hepatic cysts reported as negative with IHA; ten of them were found to be as positive with WB (41). In another study, nine patients with a negative IHA test were diagnosed as CE by clinical and imaging methods (42). Therefore, the use of a single test in the serological diagnosis of CE may be insufficient for diagnosis, so it is recommended to evaluate it after studying more than one serological method $(20,22$, $35,37)$.
In our study, a fair consistency between the IHA and WB tests was statistically determined by Cohen's Kappa analysis. For this reason, although IHA was negative according to the kit instruction manual, it was suggested that all of the samples which have IHAnegative in the titer in $\geq 1 / 80$ should be re-evaluated with the WB test.

As a result, the IHA and WB tests show little consistency. It should not be forgotten that CE diagnosis cannot be excluded as a result of a single negative serological test because of the possibility that some patients' diagnoses may not be detected by the IHA test alone. In clinical laboratories, if the WB test is used only for confirmation, it is recommended to evaluate all sera that have a positive titration with the IHA test, even if it is below the limit value. There is a continuing need for the development of test systems that are sensitive and specific, low cost, and easy to implement, which can be used today in the diagnosis of $\mathrm{CE}$.

\section{REFERENCES}

1. Saeed I, Kapel C, Saida LA, Willingham L, Nansen P. Epidemiology of Echinococcus granulosus in Arbil province, northern Iraq, 1990-1998. J Helminthol, 2000; 74 (1): 83-88.

2. Yazar S, Ozkan AT, Hökelek M, Polat E, Yilmaz H et al. Cystic echinococcosis in Turkey from 20012005. Turkiye Parazitol Derg, 2008; 32 (3): 208-220.

3. Açikgöz D, Inceboz T, Ozkara E, Korkmaz M, Birgen $N$, Uzün I. The investigation of frequency of cystic echinococcosis in the autopsies committed in the Speciality Department of Istanbul Forensic Medicine Institute. Turkiye Parazitol Derg, 2009;33(2):155157.
4. Feng $X$, Qi X, Yang L, Duan X, Fang B et al. Human cystic and alveolar echinococcosis in the Tibet Autonomous Region (TAR), China. J Helminthol, 2015; 89 (6): 671-679. doi: 10.1017/ S0022149X15000656.

5. Ito $A$, Budke $C M$. The present situation of echinococcoses in Mongolia. J Helminthol, 2015; 89 (6): 680-688. doi: 10.1017/S0022149X15000620.

6. Raimkylov KM, Kuttubaev OT, Toigombaeva VS. Epidemiological analysis of the distribution of cystic and alveolar echinococcosis in Osh Oblast in the Kyrgyz Republic, 2000-2013. J Helminthol, 2015; 89 (6): 651-654. doi: 10.1017/S0022149X15000565. 
7. Agudelo-Higuita NI, Brunetti E, McCloskey C. Cystic echinococcosis. J Clin Microbiol, 2016; 54: 518-523. doi: $10.1128 / J C M .02420-15$.

8. Deplazes P, Rinaldi L, Alvarez-Rojas CA, Torgerson PR, Harandi MF et al. Global distribution of alveolar and cystic echinococcosis. Adv Parasitol, 2017; 95: 315-493. doi: 10.1016/bs.apar.2016.11.001.

9. Yaman İ, İnceboz Ü, İnceboz T, Keyik B, Uzgören E. Primary pelvic cystic echinococcosis, Turkiye Parazitol Derg. 2015;39(2):167-70. doi:10.5152/ tpd.2015.3623.

10. Arda B, Pullukçu H, Yamazhan T, Sipahi OR, Tamsel $S$ et al. Prevalence of Echinococcus granulosus detected using enzyme immunoassay and abdominal ultrasonography in a group of students staying in a state dormitory in Turkey. Turk J Med Sci, 2009; 39 (5): 791-794. doi:10.3906/sag-0805-76.

11. Canda MȘ, Güray M, Canda T, Astarcioğlu H. The pathology of echinococcosis and the current echinococcosis problem in western Turkey (A report of pathologic features in 80 cases). Turk J Med Sci, 2003; 33 (6) 369-74.

12. Eckert J, Gemmell MA, Meslin FX, Pawtowski, ZS. WHO Manual on echinococcosis in humans and animals: A public health problem of global concern 2002: $265 \mathrm{pp}$.

13. Del Carpio M, Mercapide $\mathrm{CH}$, Salvitti JC, Uchiumi L, Sustercic J et al. Early diagnosis, treatment and follow-up of cystic echinococcosis in remote rural areas in Patagonia: impact of ultrasound training of non-specialists. PLoS Negl Trop Dis, 2012; 6: e1444. doi: $10.1371 /$ journal.pntd.0001444.

14. Moro P, Schantz PM. Echinococcosis: a review. Int J Infect Dis, 2009; 13: 125-133. doi: 10.1016/j. ijid.2008.03.037.

15. Biava MF, Dao A, Fortier B. Laboratory diagnosis of cystic hydatic disease. World J Surg, 2001; 25: 10-14.

16. Güreser AS, Ozcan O, Ozunel L, Boyacioglu Zi, Taylan-Ozkan, A. Evaluation of the radiological, biochemical and serological parameters of patients pre-diagnosed as cystic echinococcosis in Çorum, Turkey. Mikrobiyol Bul, 2015; 49(2): 231-239.
17. Cherradi $Y$, Afifi R, Khannoussi W, Firwana $M$, Rahaoui A, Benazzouz $M$ et al. Long-term results of percutaneous management of liver hydatid cysts: Experience of university hospital in endemic region. J Med Sur Res, 2016; 3 (2): 275-81.

18. Siles-Lucas M, Casulli A, Conraths FJ, Müller N. Laboratory diagnosis of Echinococcus spp. in human patients and infected animals. Adv Parasitol, 2017; 96: 159-257. doi: 10.1016/bs.apar.2016.09.003.

19. Yllmaz GR, Babür C. Diagnosis of echinococcosis. Turk Hij Den Biyol Derg, 2007; 64: 35-44.

20. Kılıç S, Babur C, Taylan-Ozkan A. Comparison of the results of indirect hemagglutination and ELISA methods for the cases prediagnosed as hydatid cyst disease. Mikrobiyol Bul, 2007; 41: 571-577.

21. Jin $Y$, Anvarov K, Khajibaev A, Hong S, Hong ST. Serodiagnosis of echinococcosis by ELISA using cystic fluid from Uzbekistan sheep. Korean J Parasitol, 2013; 51(3): 313-317. doi: 10.3347/ kjp.2013.51.3.313.

22. Beyhan YE, Babür C, Mungan M, Özkan-Taylan A. Evaluation of cystic echinococcosis suspected patients applied to National Parasitology Reference Laboratory of Public Health Institution of Turkey between 2009-2013. Turkiye Parazitol Derg, 2015; 39(1): 17-21. doi: 10.5152/tpd.2015.3646.

23. Chirag S, Fomda BA, Khan A, Malik AA, Lone GN et al. Detection of hydatid-specific antibodies in the serum and urine for the diagnosis of cystic echinococcosis in patients from the Kashmir Valley, India. J Helminthol, 2015; 89 (2): 232-237. doi: $10.1017 /$ S0022149X13000837.

24. Doiz O, Benito $R$, Younes $S$, Osuna A, Clavel A, Gomez-Lusa R. Western blot applied to the diagnosis and post-treatment monitoring of human hydatidosis. Diagn Microbiol Infect Dis, 2001; 41: $139-42$.

25. Aslan $\mathrm{M}$, Yüksel $\mathrm{P}$, Polat $\mathrm{E}$, Cakan $\mathrm{H}$, Ergin $\mathrm{S}$ et al. The diagnostic value of Western blot method in patients with cystic echinococcosis. New Microbiol, 2011; 34: 173-177. 
26. Reiter-Owona I, Grüner B, Frosch $M$, Hoerauf $A$, Kern P, Tappe D. Serological confirmatory testing of alveolar and cystic echinococcosis in clinical practice: results of a comparative study with commercialized and in-house assays. Clin Lab, 2009; 55 (1-2): 41-8.

27. Manzano R, Sánchez-Ovejero C, HernándezGonzález A, Casulli A, Siles-Lucas, M. Serological diagnosis and follow-up of human cystic echinococcosis: a new hope for the future? Biomed Res Int, 2015;1-9. doi: 10.1155/2015/428205.

28. Gwet KL. Handbook of Inter-Rate Reliability. 4th ed. Gaithersburg, USA. 2014.

29. Kern P, Menezes da Silva A, Akhan O, Müllhaupt B, Vizcaychipi KA et al. The Echinococcoses: Diagnosis, clinical management and burden of disease. Adv Parasitol, 2017; 96: 259-369. doi: 10.1016/ bs.apar.2016.09.006.

30. Zhang W, Li J, MC Manus DP. M. Concepts in immunology and diagnosis of hydatid disease. Clin Microbiol Rev, 2003 16(1):18-36.

31. Craig PS, Mc Manus DP, Lightowlers MW, Chabalgoity JA, Garcia HH et al. Prevention and control of cystic echinococcosis. Lancet Infect Dis, 2007; 7(6): 385394. doi: 10.1016/S1473-3099(07)70134-2.

32. Carmena D, Benito A, Eraso E. Antigens for the immunodiagnosis of Echinococcus granulosus infection: An update. Acta Trop, 2006: 98; 74-86. doi: 10.1016/j.actatropica.2006.02.002.

33. Auer H, Stöckl C, Suhendra S, Schneider R. Sensitivity and specificity of new commercial tests for the detection of specific Echinococcus antibodies. Wien Klin Wochenschr, 2009; 121: 37 41. doi: 10.1007/s00508-009-1233-4.
34. Hernández-González A, Santivañez S, García HH, Rodríguez S, Muñoz S et al. Improved serodiagnosis of cystic echinococcosis using the new recombinant 2B2t antigen. PLoS Negl Trop Dis, 2012; 6(7): e1714. doi: 10.1371/journal.pntd.0001714.

35. Logar J, Soba B, Kotar T. Serological evidence for human cysticechinococcosis in Slovenia. BMC Infect Dis, 2008; 8: 4-7. doi: 10.1186/1471-2334-8-63.

36. Cetinkaya U, Hamamcı B, Kaya M, Gücüyetmez $S$, Kuk $S$ et al. Investigation of anti-Echinococcus granulosus antibodies in patients with suspected cystic echinococcosis. Turkiye Parazitol Derg, 2012; 36(2): 57-60.

37. Kanwar JR, Kanwar RK, Grewal AS, Vinayak, VK. Significance of detection of immune-complexed 8 $\mathrm{kDa}$ hydatid-specific antigen for immunodiagnosis of hydatidosis. FEMS Immunol Med Microbiol, 1994; 9: 231-236.

38. Sarkari B, Rezaei Z. Immunodiagnosis of human hydatid disease: Where do we stand? World J Methodol, 2015; 5: 185-195. doi: 10.5662/wjm. v5.i4.185.

39. Akcam AT, Ulku A, Koltas IS, Izol V, Bicer OS et al. Clinical characterisation of unusual cystic echinococcosis in Southern part of Turkey. Ann Saudi Med, 2014; 34: 508-516. doi: 10.5144/0256-4947.2014.508.

40. Wuestenberg J, Gruener B, Oeztuerk S, Mason RA, Haenle $M M$ et al. Diagnostics in cystic echinococcosis: serology versus ultrasonography. Turk J Gastroenterol, 2014; 25(4): 398-404. doi: $10.5152 /$ tjg. 2014.7112 